\title{
MARINE RESERVOIR VARIATION IN THE BISMARCK REGION: AN EVALUATION OF SPATIAL AND TEMPORAL CHANGE IN $\triangle R$ AND ROVER THE LAST 3000 YEARS
}

\author{
Fiona Petchey \\ Radiocarbon Dating Laboratory, University of Waikato, Hamilton, New Zealand. Corresponding author. \\ Email: fpetchey@waikato.ac.nz \\ Sean Ulm \\ Department of Anthropology, Archaeology and Sociology, School of Arts and Social Sciences, James Cook University, \\ Cairns, Australia.
}

\begin{abstract}
Interactions between islands, ocean currents, and winds cause large-scale eddies and upwelling in the lee of islands that can result in spatial variation in the marine radiocarbon reservoir. For waters around New Ireland and the Bismarck Sea, $\Delta \mathrm{R}$ values ranging from 365 to $-320{ }^{14} \mathrm{C}$ yr have been reported (Kirch 2001; Petchey et al. 2004). Petchey et al. (2004) proposed that some of this variation was caused by seasonal reversals in the South Equatorial Current and North Equatorial Counter Current system, combined with Ekman upwelling from the Equator. McGregor et al. (2008) suggested additional complexity within this region caused by a change in the reservoir value over time in response to changing climatic conditions. We present a series of 14 new and extant published $\Delta \mathrm{R}$ and $R$ values on historic shells, combined with 8 values from archaeological terrestrial/marine pairs and U-Th dated coral, that support observations of localized variability caused by a complex interplay between seasonal currents, riverine input, and ocean eddies. On the basis of these values and oceanographic data, we divide the Bismarck Sea surface marine ${ }^{14} \mathrm{C}$ reservoir into 6 tentative subregions. In particular, our results support significant variation within channels at the southwest and southeast ends of New Britain and towards the equatorial boundary of the sea. Our results indicate that within the Bismarck Sea geographical variation appears to be more extreme than temporal over the last $3000 \mathrm{yr}$.
\end{abstract}

\section{INTRODUCTION}

For archaeologists and Quaternary researchers working in the Bismarck region, it is critical that reliable calibrated ages can be obtained from marine shell because, like most archaeological sites in the Pacific, charcoal is often highly degraded, unidentifiable, and/or scarce (see Ambrose 1988; Specht and Gosden 1997; Kirch 2001:201-2; Summerhayes 2007; Specht 2009). The global average marine reservoir age $(\operatorname{Rg}(\mathrm{t}))$ (i.e. the difference between the atmospheric ${ }^{14} \mathrm{C}$ content and that of the surface ocean) of surface water, and shells by association, is around $400{ }^{14} \mathrm{C}$ yr (Stuiver et al. 1986). By convention, this offset is corrected for when a marine radiocarbon date is calibrated using the appropriate marine curve (e.g. Marine09: Reimer et al. 2009). Regional values that deviate from $\mathrm{Rg}(\mathrm{t})$ are often expressed as $\Delta \mathrm{R}$ (the difference between the modeled ${ }^{14} \mathrm{C}$ age of surface water and the known ${ }^{14} \mathrm{C}$ age of surface water at that time). The reservoir age correction value $(R)$ is also used by some researchers $\left(R\right.$ is defined as the offset between ${ }^{14} \mathrm{C}$ age of the sample and the contemporaneous regional atmosphere at any given time). However, because the oceanic response to atmospheric ${ }^{14} \mathrm{C}$ forcing differs from the atmospheric signal, $R$ will vary over time. Consequently, $R$ cannot be used to distinguish regional differences of $\pm 100 \mathrm{yr}$ unless carbon in the samples is contemporaneous (Stuiver et al. 1998:1131). To assess the geographical variation in the marine reservoir, it is necessary therefore to use $\Delta \mathrm{R}$ because the regional ocean and the world ocean response to atmospheric forcing are assumed to be constant and cancel out any temporal change in the marine reservoir ${ }^{14} \mathrm{C}$.

$\Delta \mathrm{R}$ can be calculated from marine samples collected from known locations prior to AD 1950, from contemporaneous terrestrial/marine samples such as those found in archaeological deposits (e.g. Reimer et al. 2002; Ulm 2002; Petchey et al. 2005; Petchey and Clark 2011), or paired U-Th ${ }^{14} \mathrm{C}$ dates from corals (Edwards et al. 1993; McGregor et al. 2008). Although the database of $\Delta \mathrm{R}$ values for the Pacific is growing (http//:calib.quub.ac.uk/marine/), the interpretation and application of these $\Delta \mathrm{R}$ values to marine shell calibrations is of limited use without an evaluation of regional ocean 
circulation patterns, local marine conditions, as well as the habitat and dietary preferences of the shellfish dated (Tanaka et al. 1986; Hogg et al. 1998; Petchey and Clark 2011). In the wake of this increased interpretive complexity, shell ${ }^{14} \mathrm{C}$ dates have obtained a reputation for unreliability. Some recent reviews of ${ }^{14} \mathrm{C}$ data have ignored shell altogether (e.g. Wilmshurst et al. 2010; Rieth et al. 2011), while others have overlooked the inherent regional variability by the application of a single $\Delta$ R (e.g. Specht and Summerhayes 2007:55; White 2007:5; Summerhayes 2010).

Recent research has indicated that considerable $\Delta \mathrm{R}$ variation is possible not just in estuarine or lagoon environments where terrestrial ${ }^{14} \mathrm{C}$ input is likely (Ulm et al. 2009; Petchey and Clark 2011), but also where ocean currents meet continental landmasses, opposing currents, or island chains (Petchey et al. 2008). The Bismarck Sea has previously been identified as problematic in this respect (Petchey et al. 2004, 2005; McGregor et al. 2008). In this region, water derived from the southern branch of the South Equatorial Current (SEC) flows around the southeast tip of Papua New Guinea (PNG) and enters the Bismarck Sea through the Vitiaz Strait-between New Britain and PNG-as the New Guinea Coastal Current (NGCC) (Figure 1a,b). Further north, the flow of the more southerly branch of the SEC is broken by the Solomon Islands before entering the Bismarck Sea either through the St. George's Channel, located between New Britain and New Ireland, or the Ysabel Channel between New Ireland and Manus. The dominant northwest flow (NGCC; June/July) is reversed during the winter (January/February) monsoon and the NGCC flows back through the Vitiaz and St. George's channels (Kuroda 2000).

A significant change in the marine ${ }^{14} \mathrm{C}$ reservoir has also been identified in the period $7220-5850 \mathrm{BP}$ $\left(\Delta \mathrm{R}=-105 \pm 110\right.$ to $-265 \pm 35{ }^{14} \mathrm{C}$ yr compared with $70 \pm 60{ }^{14} \mathrm{C} \mathrm{yr}^{1}$ for a modern coral from Muschu Island). McGregor et al. (2008) attributed this to strengthening tradewinds and a shift in the Intertropical Convergence Zone, resulting in a greater influx of well-equilibrated subtropical water. McGregor et al. (2008:220-1, Table 8) also recorded an abnormal shift in $\Delta \mathrm{R}$ to $-135 \pm 35{ }^{14} \mathrm{C}$ yr around $2065 \mathrm{yr}$ ago. Recently, Yu et al. (2010) noted a shift in $\Delta \mathrm{R}$ for corals from the South China Sea dating to around 2800 to $2500 \mathrm{yr}$ ago, but of opposing magnitude $\left(180 \pm 20{ }^{14} \mathrm{C} \mathrm{yr}\right.$ and $103 \pm 20$ ${ }^{14} \mathrm{C}$ yr) to that recorded by McGregor et al. (2008). This variability remains of potential concern to archaeologists investigating human expansion at this time.

In this paper, we present results of research aimed to investigate further variation in the marine reservoir, geographically and over time in the Bismarck region, using terrestrial and marine materials from archaeological sites, U-Th dated corals, and shells from known locations collected in the 19th and early 20th centuries.

\section{METHODS}

Six pre-AD 1950 shell ${ }^{14} \mathrm{C}$ values and 1 pre-AD 1955 shell ${ }^{14} \mathrm{C}$ value are presented here for the first time. These were obtained from the Auckland War Memorial Museum in New Zealand and the Australian Museum in Sydney. An additional 8 values have been obtained from published works (Chappell and Polach 1976; Petchey et al. 2004; McGregor et al. 2008; Burr et al. 2009; Ambrose et al., in press) (Table 1). These historic values are compared to 4 archaeological shell/charcoal pairs from Watom Island (Green and Anson 2000; Petchey et al. 2005); Mussau (Kirch 2001) and Sasi in the Lou Islands (Ambrose 1988) (Table 2); and 4 paired U-Th/14 C ages on coral (Edwards et al. 1993; McGregor et al. 2008) (Table 3). The location of each site and shell/coral collection point is shown in Figure 1a.

${ }^{1}$ These values are taken directly from McGregor et al. (2008) and differ from values presented in Table 1, which have been recalculated according to the methodology outlined here. 


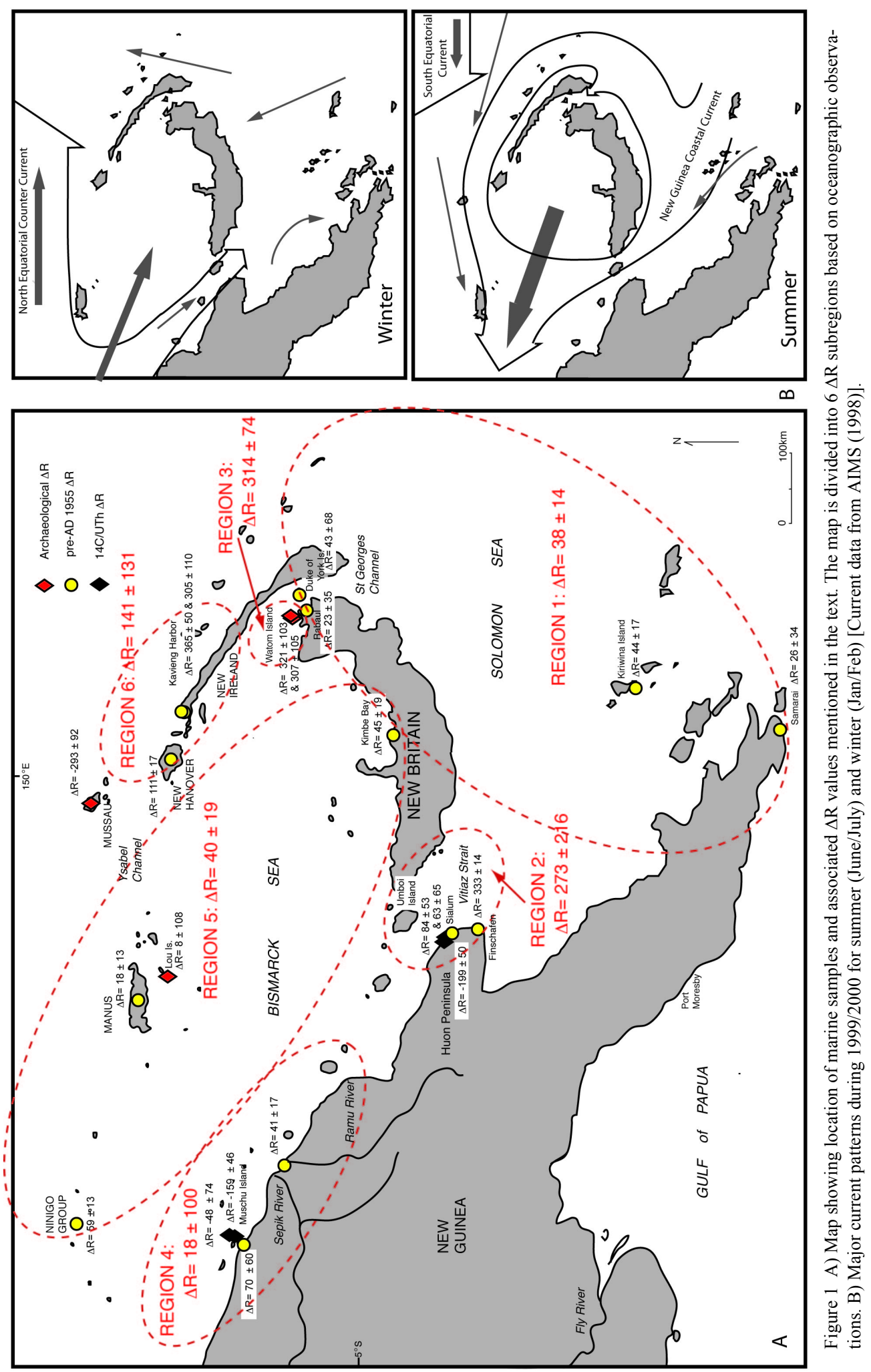


When selecting a suitable sample for $\Delta \mathrm{R}$ work, it is essential that the age of shellfish death is known (Stuiver and Braziunas 1993). For museum specimens, this information should be clearly documented. For archaeological $\Delta \mathrm{R}$, this requirement is determined by dating charcoal from short-lived plants in contexts that are contemporaneous with the shell selected. Lastly, the shell must be devoid of possible heirloom effects (e.g. food shells are usually discarded at the time of collection) or inbuilt age. Unfortunately, although a large number of archaeological dates are available in this region, few pairs conform to these strict guidelines. The most common problem involves the use of unidentified charcoals that could have inbuilt age (i.e. the growth age of the tree) (see Anderson et al. 2001; Allen and Wallace 2007) or storage age (i.e. where a period of time has elapsed from death to use by people; McFadgen 1982). Fortunately, stored wood is unlikely in the humid tropics where wood decays rapidly (Swift et al. 1979; Kirch 2001:202). This is, however, not the case for shell artifacts. Many sites also have a long occupation history, and locating suitable samples from undisturbed contexts can be problematic (see Petchey et al. 2009). The impact of these factors on $\Delta \mathrm{R}$ varies. Inbuilt age in charcoal will reduce the difference between shell and charcoal ${ }^{14} \mathrm{C}$ determinations and the $\Delta \mathrm{R}$ value will be smaller and inaccurate. Any storage age in the shell samples will result in an incorrect and larger $\Delta \mathrm{R}$ value (more positive), assuming the associated charcoal pair is short-lived.

\section{Shellfish Habitat and Dietary Considerations}

Dating shellfish and assigning a $\Delta \mathrm{R}$ can be complex because the ${ }^{14} \mathrm{C}$ content of an animal is not always in equilibrium with the ocean water in which they live. Approximately $50 \%$ of carbon in the shells of marine invertebrates is derived from metabolic sources (Tanaka et al. 1986). Because suspension-feeding shellfish predominantly consume suspended phytoplankton ${ }^{2}$ and dissolved inorganic carbon (DIC) from seawater, it is generally assumed, therefore, that they reflect surface ocean reservoir conditions (Hogg et al. 1998). It is, however, possible that carbon from sources other than ocean DIC can become incorporated in the shells (cf. Keith et al. 1964; Dye 1994; Petchey and Clark 2011). Therefore, it is important that all $\Delta \mathrm{R}$ results are evaluated with possible variations in diet, habitat, and local oceanic conditions kept in mind (Bondevik and Gulliksen in Mangerud et al. 2006: 3241).

The majority of shellfish given in Tables 1, 2, and 3 are suspension feeders (Anadara sp., Beguina sp., Comptopaallium sp., Barbatia sp., Meretrix sp., Pinctada sp., Tridacna sp., and Hyotissa sp.). In addition to suspension feeding, the giant clams (Tridacna sp.) also obtain energy from carbohydrates obtained from photosynthesis via a symbiotic relationship with zooxanthellae (singlecelled algae) (Beesley et al. 1998:333-5). Trochus sp. and Nerita sp. are both algal grazing herbivores (Beesley et al. 1998:683,697), and Nerita has previously been identified as having problematic ${ }^{14} \mathrm{C}$ values when recovered from areas of limestone bedrock due to the ingestion of terrestrial sediment while grazing (Anderson et al. 2001). Nassarius sp. are carnivorous and occupy a wide range of marine environments (Beesley et al. 1998:831, 852-3). Isotopic studies (Cook et al. 2004:882; Petchey and Clark 2011) indicate that their values will reflect their position as a secondary consumer.

With the exception of the giant clams that, depending on species, may live for $100 \mathrm{yr}$ (Hamel and Mercier 1996), the shellfish listed in Tables 1 and 3 all live for less than 50 yr. Because the $\Delta \mathrm{R}$ results for the giant clam specimens from archaeological deposits (Table 2) come from published sources, we cannot determine if the dates are of juvenile or adult specimens; however, excessive age would result in $\Delta \mathrm{R}$ values that are very large, which is not the case in this instance (see below).

\footnotetext{
${ }^{2}$ Phytoplankton are primary producers in the marine environment, deriving their carbon from DIC.
} 


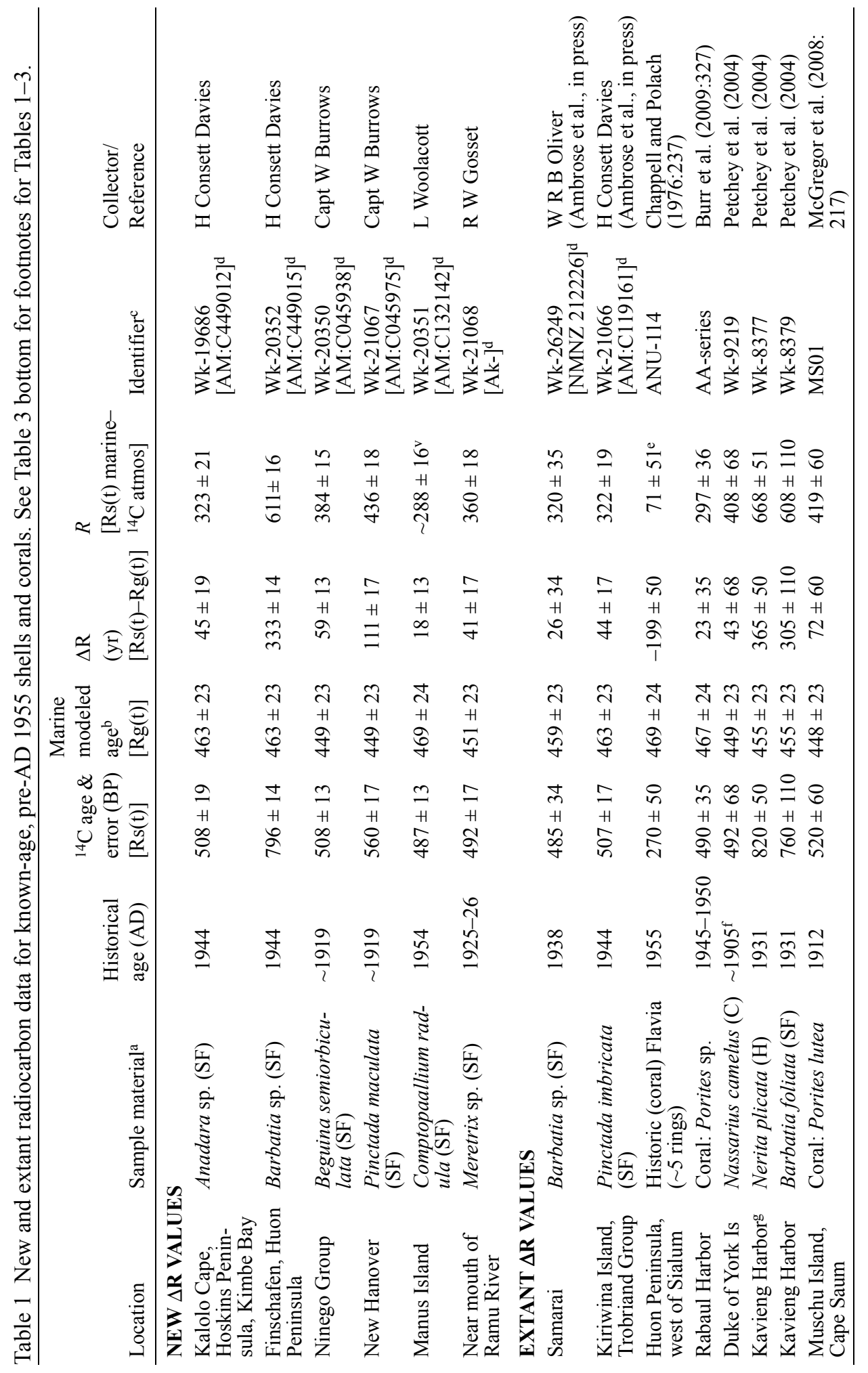




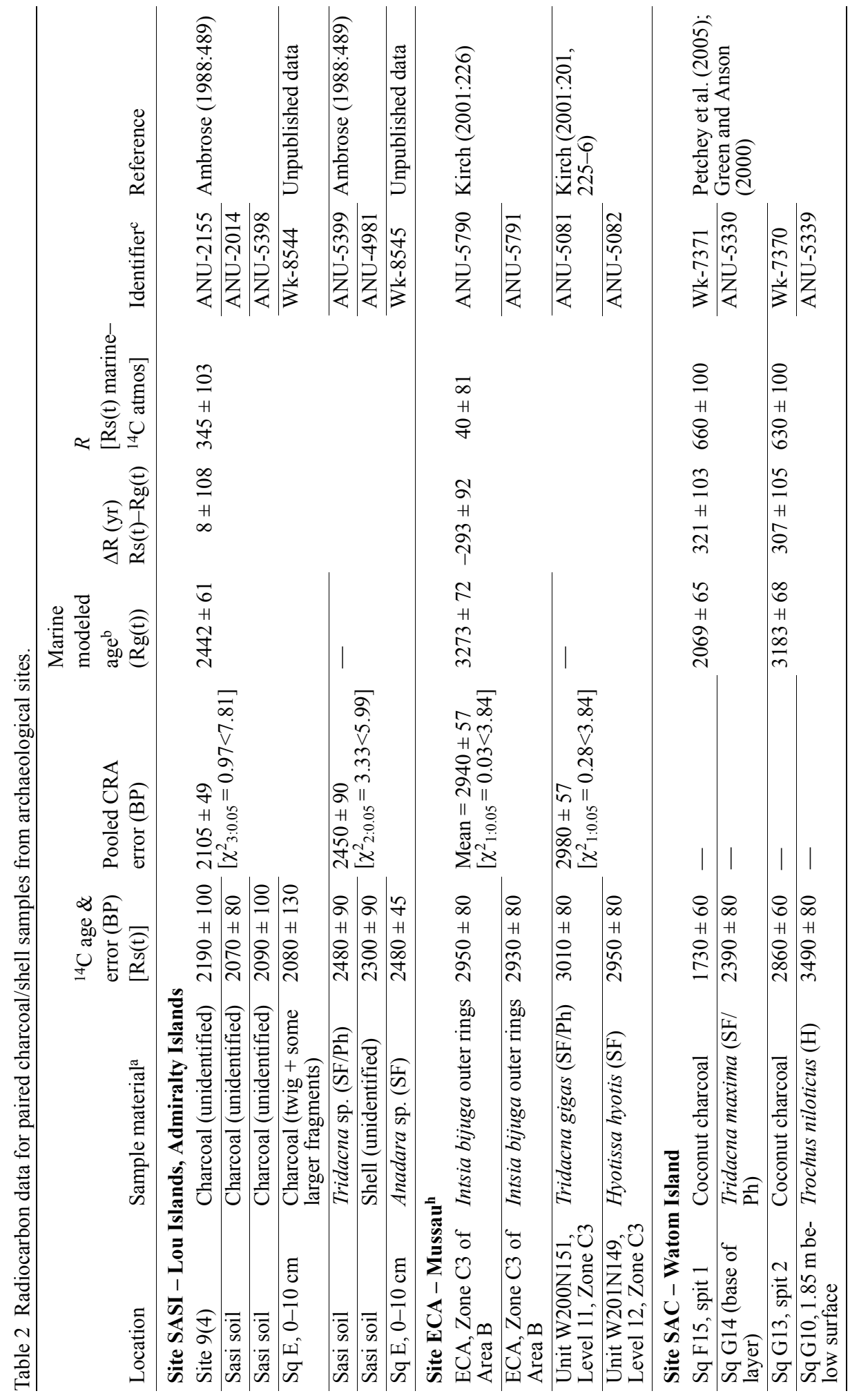




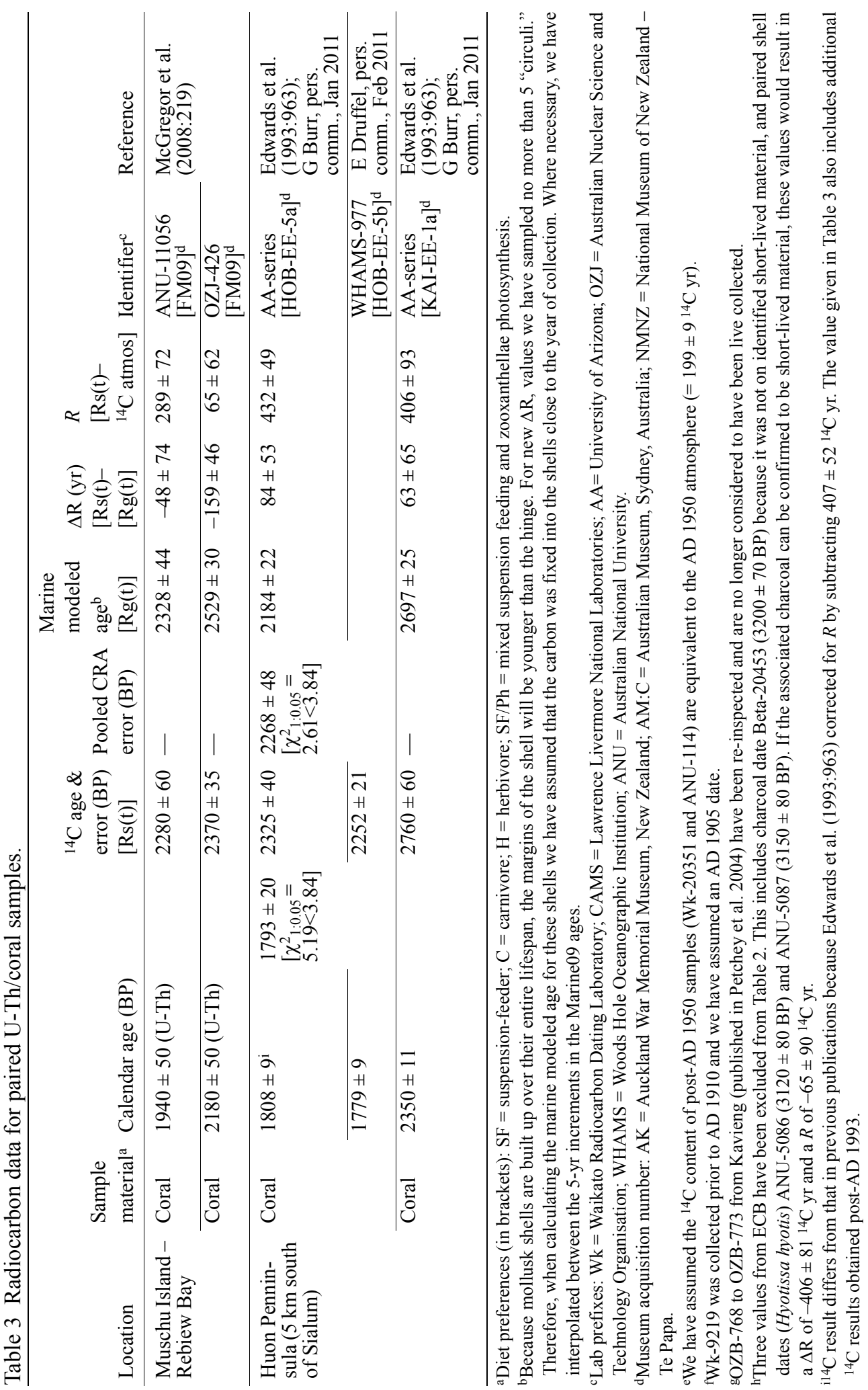


Both $R$ and $\Delta \mathrm{R}$ values are given in Tables $1-3$. For each of the ${ }^{14} \mathrm{C}$ results, the $\Delta \mathrm{R}$ for a specific location "(s)" was calculated using the formula $\mathrm{Rs}(\mathrm{t})-\mathrm{Rg}(\mathrm{t})=\Delta \mathrm{R}(\mathrm{s})$, where $\Delta \mathrm{R}(\mathrm{s})$ is the difference between the actual ${ }^{14} \mathrm{C}$ activity of the surface ocean at a particular location $[\operatorname{Rs}(\mathrm{t})]$ at that time and the global average $[\operatorname{Rg}(\mathrm{t})]$ (Marine09: Reimer et al. 2009) (Stuiver et al. 1986). For historic shell and coral samples, the $\Delta \mathrm{R}$ standard error is the $1 \sigma$ estimate of uncertainty in the conventional ${ }^{14} \mathrm{C}$ age of the shell sample; this avoids duplication of the uncertainty in the Marine 09 curve when the $\Delta \mathrm{R}$ is used for calibration (P Reimer, personal communication, 2007). $R$ is the difference between the ${ }^{14} \mathrm{C}$ age of the shell/coral sample $[\operatorname{Rs}(\mathrm{t})]$ and the atmospheric ${ }^{14} \mathrm{C}$ age (Table 1$)$.

For archaeological pairs (Table 2), an estimate of the atmospheric calibration curve error (IntCal09: Reimer et al. 2009) over the $1 \sigma$ span of the ${ }^{14} \mathrm{C}$ age was used to derive the calculated marine modeled age $[\operatorname{Rg}(\mathrm{t})]$ error, whereby, atmospheric age $\sigma=\left(\sigma^{14} \mathrm{C}\right.$ age $^{2}+$ average of calibration curve error $\left.{ }^{2}\right)$. The $\Delta R$ standard error is calculated by the formula $\Delta R \sigma=\left(\sigma \operatorname{Rg}(t)^{2}+\sigma R s(t)^{2}\right)$. Similarly, the U-Th coral ages (Table 3 ) were converted to atmospheric ${ }^{14} \mathrm{C}$ ages using the IntCal09 curve whereby the equivalent atmospheric ${ }^{14} \mathrm{C}$ age is the median of the oldest and youngest ${ }^{14} \mathrm{C}$ ages across the $\mathrm{U}$ Th $(1 \sigma)$ age range.

All $R$ values have been calculated using the IntCal09 data sets (Reimer et al. 2009). The use of the Northern Hemisphere data set is based on the recommendations of McCormac et al. (2004:1088) and Petchey et al. (2009) whereby the ${ }^{14} \mathrm{C}$ boundary between the atmosphere of the Southern and Northern hemispheres lies along the thermal equator, commonly called the Intertropical Convergence Zone. This varies from the procedure used by Burr et al. (2009) for this region whereby reservoir ages were calculated by subtracting Southern Hemisphere atmospheric data derived from McCormac et al. (2004) and Hua et al. (2000, 2003).

Even when samples are carefully selected according to the prerequisites listed above, there are a number of uncertainties with the ${ }^{14} \mathrm{C}$ data because of the postulated time of carbon uptake before collection, the influence of diet and habitat, and short-term fluctuation in the water masses. To estimate the amount of uncertainty that needs to be added to the $\Delta \mathrm{R}$ value by the nonuniform ${ }^{14} \mathrm{C}$ content of the shellfish, we have calculated the weighted mean for each group (Table 1) using the chi squared $\left(\chi^{2}\right)$ test to evaluate the internal variability in $\Delta \mathrm{R}$ values. Then, using the methodology recommended by Bondevik and Gulliksen in Mangerud et al. (2006), if the group has additional measurement variability (as indicated if $\chi^{2} /(n-1)$ is $>1$ ), we have added an additional uncertainty (external variance) to the $\Delta \mathrm{R}$. In this instance, the uncertainty is calculated by $\sqrt{ }\left(s_{\Delta \mathrm{R} p o o l e d}+\sigma_{\text {ext }}^{2}\right)$, whereby the external standard deviation $\left(\sigma_{\text {ext }}\right)$ is determined by subtracting the ${ }^{14} \mathrm{C}$ measurement variance from the total population variance and obtaining the square root (e.g. $\sigma_{\text {ext }}=\sqrt{ }\left(\sigma_{\text {pop }}^{2}-\sigma_{\text {meas }}^{2}\right)$ ) (see Mangerud et al. 2006:3241-2 for explanation). When $\chi^{2} /(n-1)$ is 1 , the uncertainty on the individual measurements explains the variations within the group of $\Delta \mathrm{R}$ values and the weighted mean is used.

\section{RESULTS}

A total of $22 \Delta R$ values from the southwest tropical Pacific dating to within the last $3300 \mathrm{yr}$ are presented in Tables 1-3. $\Delta \mathrm{R}$ values range from $365 \pm 50$ to $-293 \pm 71{ }^{14} \mathrm{C} \mathrm{yr}-\mathrm{a}$ spread of around 700 ${ }^{14} \mathrm{C}$ yr (Figure 1). The greatest variation in $\Delta \mathrm{R}$ at 1 location occurs around the Huon Peninsula where values range from $333 \pm 14$ to $-199 \pm 50{ }^{14} \mathrm{C}$ yr. The most positive $\Delta \mathrm{R}$ have been recorded for New Hanover $\left(111 \pm 17{ }^{14} \mathrm{C}\right.$ yr), Kavieng Harbor at the northern tip of New Ireland $(365 \pm 50$ and $305 \pm$ $110{ }^{14} \mathrm{C}$ yr), Finschafen $\left(333 \pm 14{ }^{14} \mathrm{C}\right.$ yr), and for archaeological deposits on Watom Island $(307 \pm$ 105 and $321 \pm 103{ }^{14} \mathrm{C}$ yr). Unusually low $\Delta \mathrm{R}$ have been measured on archaeological shells from Mussau $\left(-293 \pm 92{ }^{14} \mathrm{C}\right.$ yr), located just outside of the Bismarck Sea. This range of variation within 
a relatively small area means it is impractical to apply a regional $\Delta \mathrm{R}$ value as has been possible for the central South Pacific Gyre region $\left(\Delta \mathrm{R}=5.5 \pm 21{ }^{14} \mathrm{C}\right.$ yr) (Petchey et al. 2008; Table 1). Although we recognize that this region is highly complex and the variability present is large, we argue that, when local oceanographic conditions are taken into consideration, it is possible to apply valid and statistically sound subregional $\Delta \mathrm{R}$ values that incorporate the variation observed.

Ongoing research within the wider Pacific has indicated that wide shifts in $\Delta \mathrm{R}$ can occur on the leeward side of islands, where fast-flowing currents and eddy formation result in the upwelling of ${ }^{14} \mathrm{C}$ depleted waters (e.g. the NEC and NECC flows that pass Hawai'i [Petchey 2009] and Palau [Petchey and Clark 2010], respectively, that exceed $25 \mathrm{~cm} \mathrm{~s}^{-1}$ ). Seasonal current reversals further compound this affect in the narrow channels that feed into the Bismarck Sea. Chlorophyll concentration and sea surface temperature satellite data reported in Steinberg et al. (2006) indicate intermittent upwelling along the southeast coast of New Britain, Kimbe Bay, southwest Manus, Mussau, and along the Papua New Guinea coast near the Vitiaz and George's channels. Variable, and sometimes very high, $\Delta \mathrm{R}$ values are recorded around the Vitiaz, St. George's, and Ysabel channels in keeping with these observations (Tables 1-3). These values appear to be higher in the lee of the dominant current direction; for example, in St. George's Channel the dominant flow all year round is from the Solomon Sea to the Bismarck Sea with speeds that can reach $100 \mathrm{~cm} \mathrm{~s}^{-1}$ (Lindstrom et al. 1990:182). Values of $307 \pm 105$ and $321 \pm 103{ }^{14} \mathrm{C}$ yr $\left(\Delta \mathrm{R}\right.$ average $\left.=314 \pm 74{ }^{14} \mathrm{C} \mathrm{yr} ; \chi^{2}{ }_{1: 0.05}=0.01<3.84\right)$ for Watom Island on the western side of the channel are typical of values found in upwelling zones, and are most likely caused by eddies, while those to the southeast $\left(\Delta \mathrm{R}=43 \pm 68{ }^{14} \mathrm{C}\right.$ yr for the Duke of York Islands and $23 \pm 35{ }^{14} \mathrm{C}$ yr for Rabaul Harbor) are lower and more in keeping with values reported by Ambrose et al. (in press) from Kiriwina and Samarai islands (southeastern Papua New Guinea) $\left(\Delta \mathrm{R}=44 \pm 17\right.$ and $26 \pm 34{ }^{14} \mathrm{C} \mathrm{yr}$, respectively $)$ and those found in the Coral and Solomon seas (Petchey et al. 2004). The combined $\Delta \mathrm{R}$ for the Duke of York Islands, Samarai, Kiriwina Island, and Rabaul is $38 \pm 14{ }^{14} \mathrm{C}$ yr $\left(\chi^{2} 3: 0.05=0.44<7.81\right.$; no external variance). This is indistinguishable from the South Pacific Gyre average of $5.5 \pm 21{ }^{14} \mathrm{C} \mathrm{yr}^{3}$

The pattern for Vitaz Strait is more complicated. In January, the flow is concentrated between Umboi Islands and New Guinea and flows from the Bismarck Sea into the Solomon Sea, reaching speeds of $110 \mathrm{~cm} \mathrm{~s}^{-1}$. In June/July, this reverses, but speeds close to $40 \mathrm{~cm} \mathrm{~s}^{-1}$ are still possible (Lindstrom et al. 1990:182). The high $\Delta \mathrm{R}$ of $333 \pm 14{ }^{14} \mathrm{C}$ yr for Finschafen at the tip of Huon Peninsula may reflect similar turbulent upwelling (compare with $\Delta \mathrm{R}$ values of $84 \pm 53$ and $63 \pm 65{ }^{14} \mathrm{C}$ $\mathrm{yr}$ for U-Th coral from $5 \mathrm{~km}$ south of Sialum and $-199 \pm 50{ }^{14} \mathrm{C}$ yr for ${ }^{14} \mathrm{C}$ pre-AD 1955 corals west of Sialum). Support for these observations comes from chlorophyll and sea surface temperature satellite data (Steinberg et al. 2006:10-8), which indicates large-scale turbulence in these channels that varies with wind strength and season. The narrow passage between Umboi Island and the western end of New Britain is considered to play a smaller role in the Solomon/Bismarck Sea interaction (Lindstrom et al. 1990:173). The $-199 \pm 50{ }^{14} \mathrm{C}$ yr value for west Salium is unusual. This may be a reflection of the date of a post-bomb growth date $(\mathrm{AD} 1955)$ and needs retesting. The combined $\Delta \mathrm{R}$ for the Huon Peninsula is $273 \pm 13{ }^{14} \mathrm{C}$ yr $\left(\chi^{2} 3: 0.05=130.6<7.81\right)$ with an additional uncertainty of $216 \mathrm{yr}$ reflecting the variability present in this subregion.

Petchey et al. (2005) also hypothesized that upwelling along the New Guinea coastline in response to seasonal reversals in the SEC and NEC may contribute to higher $\triangle \mathrm{R}$ values at the western edge of the Bismarck Sea. Our results do not inconclusively support this hypothesis. Values for the New

\footnotetext{
${ }^{3}$ This value excludes $\Delta \mathrm{R}$ results from the Solomon Island chain, which is also likely to be affected by wakes and eddies caused by the SEC flow through the islands.
} 
Guinea coastline are fairly low, but variable (subregional $\Delta \mathrm{R}=18 \pm 15{ }^{14} \mathrm{C}$ yr; $\chi^{2}$ 3:0.05 $=18.24<$ 7.81; external variance $=100$ ). Some of the ${ }^{14} \mathrm{C}$-enriched $\Delta \mathrm{R}$ values (e.g. $-159 \pm 46$ and $-48 \pm 74{ }^{14} \mathrm{C}$ $\mathrm{yr}$ for Muschu Island U-Th dated corals) could be caused by the addition of terrestrial matter via the Sepik and Ramu rivers, offsetting any coastal upwelling. The influence of the Sepik River in particular is far reaching, with a freshwater plume that can stretch to the Admiralty Islands $300 \mathrm{~km}$ away (Cresswell 2000; Steinberg et al. 2006:32).

$\Delta \mathrm{R}$ values collected from islands within the center of the Bismarck Sea (Manus $\Delta \mathrm{R}=18 \pm 13{ }^{14} \mathrm{C}$ yr; Lou Island $\Delta \mathrm{R}=8 \pm 108{ }^{14} \mathrm{C}$ yr; Ninego Group $\Delta \mathrm{R}=59 \pm 13{ }^{14} \mathrm{C}$ yr; Hoskins Peninsula, Kimbe Bay $\Delta \mathrm{R}=45 \pm 19{ }^{14} \mathrm{C}$ yr) (subregional $\Delta \mathrm{R}=40 \pm 8{ }^{14} \mathrm{C}$ yr; $\chi^{2}{ }_{3: 0.05}=5.15<7.81$; external variance $=$ 19) are comparable to values from the northern branch of the SEC (Nauru $=9 \pm 5{ }^{14} \mathrm{C}$ yr [Guilderson et al. 1998]) and the central South Pacific Gyre average $\left(5.5 \pm 21^{14} \mathrm{C}\right.$ yr). This value probably reflects calmer, highly mixed surface water conditions at the center of the sea, resulting in a return to typical surface ocean values. Ocean temperatures in this area do, however, indicate that significant upwelling is possible in the lee of Manus Island (Steinberg et al. 2006:33) as the SEC is deflected around New Ireland.

Petchey et al. (2004) have suggested that high values around Kavieng Harbor $(\Delta \mathrm{R}=365 \pm 50$ and $305 \pm 110{ }^{14} \mathrm{C}$ yr) could reflect equatorial or coastal upwelling along New Ireland. The $\Delta \mathrm{R}$ of $111 \pm 17{ }^{14} \mathrm{C}$ yr for New Hanover is more enriched, but in keeping with these observations (subregional $\Delta \mathrm{R}=141 \pm 16{ }^{14} \mathrm{C}$ yr; $\chi^{2} 2: 0.05=25.4<5.99$; external variance $=131$ ).

The only $\Delta \mathrm{R}$ that cannot be explained immediately by oceanographic circulation patterns are from Tridacna gigas and Hyotissa hyotis recovered from the archaeological site of ECA on Eloaua Island, Mussau (Table 2). Kirch (2001:201-2) calculated an average $\Delta \mathrm{R}$ correction of $-320{ }^{14} \mathrm{C} \mathrm{yr}$ for shell/ charcoal pairs from 2 localities (ECA and ECB), but this value did not give acceptable calibrated ${ }^{14} \mathrm{C}$ ages for Turbo sp. gastropods from Mussau. Kirch (2001:202-4) therefore suggested that these surge zone gastropods had been influenced by atmospheric ${ }^{14} \mathrm{C}$. Petchey et al. (2008) has attributed several negative $\Delta \mathrm{R}$ values in the South Pacific Gyre to the absorption of atmospheric $\mathrm{CO}_{2}$ associated with enhanced biological production or wind and wave action in shallow lagoon environments. A similar explanation for surge zone gastropods would, however, result in $\Delta \mathrm{R}$ values being more enriched in ${ }^{14} \mathrm{C}$ than the bivalves and, therefore, seems to be an unlikely explanation for the observed offset. While we cannot rule out the possibility of sample displacement in the archaeological deposits, this also seems to be an unlikely explanation for the negative $\Delta \mathrm{R}$ values given the consistency in $\Delta \mathrm{R}$ offset between the 2 sites (see footnote $\mathrm{h}$ to the Tables for ECB $\Delta \mathrm{R}$ pairs). Given the current available information for Mussau and lagoon environments, we suggest that this unusual $\Delta R$ value is an area for further research and, until resolved, remains an unknown error in establishing a reliable shell chronology for the entire Pacific region.

\section{Change over Time}

There are relatively few studies of changing $R$ over time in the Pacific. Coral core and foraminifera data from the central Pacific Gyre region suggest negligible change in the surface marine reservoir over the last 11,000 yr (Bard 1988; Sikes et al. 2000; Paterne et al. 2004) despite several periods of major climatic change noted during this time period. In particular, Haberle and David (2004:166-9) have identified 2 periods of major climate change reflected in burning data and other climate proxies from the Australasian tropics at around 6000-5000 cal yr BP, with increasing El Niño events peaking around 3000-1000 cal yr BP. There is also a growing body of archaeological evidence pointing to the influence of changing climate patterns on human settlement and culture at this time (Allen 2006; Anderson et al. 2006; Nunn 2007; Clark and Reepmeyer 2012). McGregor et al. (2008) sug- 
gested that ocean-atmosphere interactions in the western equatorial Pacific triggered El Niño events that pushed equatorial waters eastward, causing marine ${ }^{14} \mathrm{C}$ reservoir variation at Muschu Island between $7220-5850 \mathrm{BP}\left(\Delta \mathrm{R}=-105 \pm 110\right.$ to $\left.-265 \pm 35{ }^{14} \mathrm{C} \mathrm{yr} ; R=185 \pm 30{ }^{14} \mathrm{C} \mathrm{yr}\right)$. This was followed by the onset of modern El Niño activity at around 5850-5420 BP that would have enhanced the intrusion of ${ }^{14} \mathrm{C}$-depleted equatorial waters and a return to modern values. McGregor et al. (2008:220) also identified a shift at around $2065 \mathrm{BP}$ to a $\Delta \mathrm{R}$ of $-135 \pm 35{ }^{14} \mathrm{C} \mathrm{yr}\left(R=215 \pm 50{ }^{14} \mathrm{C}\right.$ $\mathrm{yr})$, but data is limited and this value may reflect influence from the Sepik River or recrystallization of the coral. Yu et al. (2010) also noted a shift in $\Delta \mathrm{R}$ for corals from the South China Sea at around $2800 \mathrm{yr}$ ago, but again, data is limited. In contrast, evidence compiled by Petchey et al. (2009) and Petchey and Clark (2011) indicates stability in $\Delta \mathrm{R}$ over the last $\sim 3000 \mathrm{yr}$ in the South Pacific Gyre.

For the wider Bismarck Sea/Solomon Sea area, we have identified 4 locations, covering some time depth (AD $1950[0 \mathrm{BP}]$ to $\sim 3000 \mathrm{yr} \mathrm{BP}$ ), where $\Delta \mathrm{R} / R$ are available; Muschu, Watom Island, and Manus Island (Tables 1-3). Three $\Delta \mathrm{R}$ values are given from Muschu: $-48 \pm 74$ (at $1940 \pm 50 \mathrm{BP}$ ); $159 \pm 46$ (at $2180 \pm 50 \mathrm{BP}$ ); and $72 \pm 60{ }^{14} \mathrm{C}$ yr at $\mathrm{AD} 1912$. These 3 values, in an area where river plumes have already been identified as a potential major influence, are outside statistics $\left(\chi^{2} 2: 0.05=\right.$ $9.43<5.99)$ and significant variability is also present in the $R$ values $\left(\chi^{2} 2: 0.05=17.08<5.99\right)$. However, deposits dating to $\sim 1650 \mathrm{cal} \mathrm{BP}\left(\Delta \mathrm{R}=321 \pm 103{ }^{14} \mathrm{C}\right.$ yr $)$ and $\sim 3000 \mathrm{cal} \mathrm{BP}(\Delta \mathrm{R}=307 \pm 105$ ${ }^{14} \mathrm{C}$ yr) from Watom Island are statistically indistinguishable $\left(\Delta \mathrm{R}: \chi^{2}{ }_{1: 0.05}=0.01<3.84 ; R: \chi^{2}{ }_{1: 0.05}=\right.$ $0.05<3.84$ ). Similarly, an AD 1954 shell from the Sasi site on Manus Island gave a $\Delta \mathrm{R}$ of $18 \pm 13$ ${ }^{14} \mathrm{C}$ yr compared to a value of $8 \pm 108{ }^{14} \mathrm{C}$ yr in $\sim 2100 \mathrm{cal} \mathrm{BP}\left(\Delta \mathrm{R}: \chi^{2} 1: 0.05=0.01<3.84 ; R: \chi^{2} 1: 0.05=\right.$ $0.30<3.84)$. While these limited results are far from conclusive, they support the observation that geographical variation in oceanographic conditions in the Bismarck Sea has more impact on the marine ${ }^{14} \mathrm{C}$ reservoir in the period $<3000 \mathrm{yr} \mathrm{BP}$ than changing reservoir conditions during this time. This is an area that requires further research.

\section{CONCLUSION}

Our results suggest significant variations in the marine ${ }^{14} \mathrm{C}$ reservoir are possible across the Bismarck region. Using ${ }^{14} \mathrm{C}$ from surface ocean carbonates and oceanographic observations, we have identified 6 subregions:

- Region 1 (Coral Sea - including Duke of York Islands, Samarai, Kiriwina Island, and Rabaul), $\Delta \mathrm{R}=38 \pm 14{ }^{14} \mathrm{C}$ yr;

- Region 2 (Huon Peninsula/Vitiaz Strait), $\Delta \mathrm{R}=273 \pm 216^{14} \mathrm{C} \mathrm{yr}$;

- Region 3 (St. George's Channel - west), $\Delta \mathrm{R}=314 \pm 74{ }^{14} \mathrm{C}$ yr;

- Region 4 (eastern New Guinea coastline), $\Delta \mathrm{R}=18 \pm 100{ }^{14} \mathrm{C} \mathrm{yr}$;

- Region 5 (central Bismarck Sea), $\Delta \mathrm{R}=40 \pm 19{ }^{14} \mathrm{C}$ yr; and

- Region 6 (equatorial islands), $\Delta \mathrm{R}=141 \pm 131{ }^{14} \mathrm{C} \mathrm{yr}$.

This suggests that at these locations geographical variation appears to be more extreme than temporal over the last $3000 \mathrm{yr}$, but more research is needed to confirm this observation and establish the pattern for periods older than $3000 \mathrm{yr}$ BP. Moreover, significant variation between some shell taxa and some near-shore environments is likely and adds uncertainty to these divisions. This is also an area for further research.

Shellfish remains dominate many coastal archaeological sites in the Pacific. Shells therefore provide the greatest opportunity to develop a comprehensive understanding of colonization and changes in settlement patterns and culture since they are sensitive to both the timing and mode of change. Although these new $\Delta \mathrm{R}$ values go a long way towards improving the reliability of shell dates in this 
region, the limited number of ${ }^{14} \mathrm{C}$ dates on charcoal from short-lived materials remains a significant stumbling block to refining both $\Delta \mathrm{R}$ and chronological issues generally. However, far from being seen as a limitation to obtaining reliable calibrated ${ }^{14} \mathrm{C}$ dates on shell, it should be recognized that the observed complexity within the marine reservoir reflects our growing understanding of ${ }^{14} \mathrm{C}$ in nature, and provides an opportunity for greater dating resolution than has hitherto been available in this region.

\section{ACKNOWLEDGMENTS}

First and foremost, we would like to thank Roger Green who took an avid interest in $\Delta \mathrm{R}$ values in this region. This paper would not have been possible without the selfless assistance from the following: Wal Ambrose (Australian National University); George Burr (University of Arizona); Ellen Druffel (Department of Earth System Science, University of California, Irvine); and Ian Loch (Australian Museum, Sydney). This paper was written while Petchey was an Honorary Research Advisor at the Aboriginal and Torres Strait Islander Studies Unit, University of Queensland.

\section{REFERENCES}

Australian Institute of Marine Science (AIMS). 1998. Coral Sea region billfish atlas: currents. AIMS Research, Australian Institute of Marine Science. Available at http://www.aims.gov.au/pages/reflib/billfish/ pages/bf_05.html. Accessed 25 August 2003.

Allen MS. 2006. New ideas about late Holocene climate variability in the central Pacific. Current Anthropology 47(3):521-35.

Allen MS, Wallace R. 2007. New evidence from the East Polynesian gateway: substantive and methodological results from Aitutaki, southern Cook Islands. Radiocarbon 49(3): 1-17.

Ambrose WR. 1988. An early bronze artefact from Papua New Guinea. Antiquity 62(236):483-91

Ambrose W, Petchey F, Swadling P, Beran H, Bonshek L, Szabo K, Bickler S, Summerhayes G. In press. Engraved prehistoric Conus shell artifacts from southeastern Papua New Guinea: their antiquity, motifs and distribution. Australian Archaeometry.

Anderson A, Higham T, Wallace R. 2001. The radiocarbon chronology of the Norfolk Island archaeological sites. Records of the Australian Museum, Supplement 27:33-42.

Anderson A, Chappell J, Gagan M, Grove R. 2006. Prehistoric maritime migration in the Pacific islands: an hypothesis of ENSO forcing. The Holocene 16(1):16.

Bard E. 1988. Correction of accelerator mass spectrometry ${ }^{14} \mathrm{C}$ ages measured in planktonic foraminifera: paleoceanographic implications. Paleoceanography 3(6):635-45.

Beesley PL, Ross GJB, Wells A, editors. 1998. Mollusca: The Southern Synthesis. Fauna of Australia. Volume 5. Melbourne: CSIRO Publishing.

Burr GS, Beck JW, Corrège T, Cabioch G, Taylor FW, Donahue DJ. 2009. Modern and Pleistocene reservoir ages inferred from South Pacific corals. Radiocarbon 51(1):319-35.
Chappell J, Polach HA. 1976. Holocene sea-level change and coral-reef growth at Huon Peninsula, Papua New Guinea. Geological Society of America Bulletin 87: 235-40.

Clark C, Reepmeyer C. 2012. Last millennium climate change in the occupation and abandonment of Palau's Rock Islands. Archaeology in Oceania 47(1):29-38.

Cook GT, MacKenzie AB, Muir GKP, Mackie G, Gulliver P. 2004. Sellafield-derived anthropogenic ${ }^{14} \mathrm{C}$ in the marine intertidal environment of the $\mathrm{NE}$ Irish Sea. Radiocarbon 46(2):877-83.

Cresswell GR. 2000. Coastal currents of northern Papua New Guinea, and the Sepik River outflow. Marine Freshwater Research 51:553-64.

Dye T. 1994. Apparent ages of marine shells: implications for archaeological dating in Hawaii. Radiocarbon 36(1):51-7.

Edwards RL, Beck JW, Burr GS, Donahue DJ, Chappell JMA, Bloom AL, Druffel ERM, Taylor FW. 1993. A large drop in atmospheric ${ }^{14} \mathrm{C} /{ }^{12} \mathrm{C}$ and reduced melting in the younger Dryas, documented with ${ }^{230} \mathrm{Th}$ ages of corals. Science 260(5110):962-8.

Green RC, Anson D. 2000. Excavations at Kainapirina (SAC), Watom Island, Papua New Guinea. New Zealand Journal of Archaeology 20(1998):29-94.

Guilderson TP, Schrag DP, Kashgarian M, Southon J. 1998. Radiocarbon variability in the western equatorial Pacific inferred from a high-resolution coral record from Nauru Island. Journal of Geophysical Research 103(C11):24,641-50.

Haberle SG, David B. 2004. Climates of change: human dimensions of Holocene environmental change in low latitudes of the PEPII transect. Quaternary International 118-119:165-79.

Hamel JF, Mercier A. 1996. The secret of the giant clam. Freshwater and Marine Aquarium 19(5):112.

Hogg A, Higham TFG, Dahm J. 1998. Radiocarbon dating of modern marine and estuarine shellfish. Radio- 
carbon 40(2):975-84.

Hua Q, Barbetti M, Jacobsen GE, Zoppi U, Lawson EM. 2000. Bomb radiocarbon in annual tree rings from Thailand and Australia. Nuclear Instruments and Methods in Physics Research B 172(1-4):359-65.

Hua Q, Barbetti M, Zoppi U, Chapman DM, Thomson B. 2003. Bomb radiocarbon in tree rings from New South Wales, Australia: implications for dendrochronology, atmospheric transport, and air-sea exchange of $\mathrm{CO}_{2}$. Radiocarbon 45(3):431-47.

Keith ML, Anderson GM, Eichler R. 1964. Carbon and oxygen isotopic composition of mollusk shells from marine and fresh-water environments. Geochimica et Cosmochimica Acta 28(10-11):1757-86.

Kirch PV. 2001. A radiocarbon chronology for the Mussau Islands. In: Kirch PV, editor. Lapita and Its Transformations in Near Oceania: Archaeological Investigations in the Mussau Islands, Papua New Guinea, 1985-88. Volume 1 Introduction, Excavations, Chronology. Contribution No. 59. Archaeological Research Facility, University of California at Berkeley. p 196-222.

Kuroda Y. 2000. Variability of currents of the northern coast of New Guinea. Journal of Oceanography 56(1):103-16.

Lindstrom E, Butt J, Lukas R, Godfrey S. 1990. The flow through Vitiaz Str. and St George's Channel, Papua New Guinea. In: Pratt L, editor. The Physical Oceanography of Sea Straits. Dordtrecht: Kluwer Academic. p 171-89.

Mangerud J, Bondevik S, Gulliksen S, Hufthammer AK, Høisæter T. 2006. Marine ${ }^{14} \mathrm{C}$ reservoir ages for 19th century whales and molluscs from the North Atlantic. Quaternary Science Reviews 25(23-24):3228-45.

McCormac FG, Hogg AG, Blackwell PG, Buck CE, Higham TFG, Reimer PJ. 2004. SHCal04 Southern Hemisphere calibration, 0-11.0 cal kyr BP. Radiocarbon 46(3):1087-92.

McFadgen BG. 1982. Dating New Zealand archaeology by radiocarbon. New Zealand Journal of Science 25: 379-92.

McGregor HV, Gagan MK, McCulloch MT, Hodge E, Mortimer G. 2008. Mid-Holocene variability in the marine ${ }^{14} \mathrm{C}$ reservoir age for northern coastal Papua New Guinea. Quaternary Geochronology 3(3):21325.

Nunn PD. 2007. Climate, Environment and Society in the Pacific during the Last Millennium. Amsterdam: Elsevier.

Ortlieb L, Vargas G, Saliège J-F. 2011. Marine radiocarbon reservoir effect along the northern Chile-southern

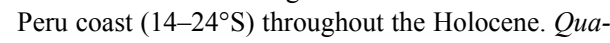
ternary Research 75(1):91-103.

Paterne M, Ayliffe LK, Arnold M, Caioch G, TisnératLaborde N, Hatté C, Douville E, Bard E. 2004. Paired ${ }^{14} \mathrm{C}$ and ${ }^{230} \mathrm{Th} / \mathrm{U}$ dating of surface corals from the Marquesas and Vanuatu (subequatorial Pacific) in the
3000 to 15,000 cal yr interval. Radiocarbon 46(2): 551-6.

Petchey F. 2009. Dating marine shell in Oceania: issues and prospects. In: Fairbairn A, O'Connor S, Marwick B, editors. New Directions in Archaeological Science. Terra Australis, 28. Canberra: Pandanus Books, Research School of Pacific and Asian Studies, ANU. p 157-72.

Petchey F, Clark G. 2010. A $\Delta$ R for the Palau Islands: an evaluation of extant and new $\Delta R$ values and their application to archaeological deposits at Ulong. Journal of Island Archaeology 5:236-52.

Petchey F, Clark G. 2011. Tongatapu hardwater: investigation into the ${ }^{14} \mathrm{C}$ marine reservoir offset in lagoon, reef and open ocean environments of a limestone island. Quaternary Geochronology 6(6):539-49.

Petchey F, Phelan M, White P. 2004. New $\Delta$ R values for the southwest Pacific Ocean. Radiocarbon 46(2): 1005-14.

Petchey F, Green R, Jones M, Phelan M. 2005. A local marine reservoir correction value $(\Delta \mathrm{R})$ for Watom Island, Papua New Guinea. New Zealand Journal of Archaeology 26:29-40.

Petchey F, Anderson A, Zondervan A, Ulm S, Hogg A. 2008. New marine $\Delta \mathrm{R}$ values for the South Pacific Subtropical Gyre region. Radiocarbon 50(3):373-97.

Petchey F, Allen MS, Addison D, Anderson A. 2009. Stability in the South Pacific surface marine ${ }^{14} \mathrm{C}$ reservoir over the last 750 years: evidence from American Samoa, the southern Cook Islands and the Marquesas. Journal of Archaeological Science 36(10):2234-43.

Reimer PJ, McCormac FG, Moore J, McCormick F, Murray EV. 2002. Marine radiocarbon reservoir corrections for the mid- to late Holocene in the eastern subpolar North Atlantic. The Holocene 12(2):129-35.

Reimer PJ, Baillie MGL, Bard E, Bayliss A, Beck JW, Blackwell PG, Bronk Ramsey C, Buck CE, Burr GS, Edwards RL, Friedrich M, Grootes PM, Guilderson TP, Hajdas I, Heaton TJ, Hogg AG, Hughen KA, Kaiser KF, Kromer B, McCormac FG, Manning SW, Reimer RW, Richards DA, Southon JR, Talamo S, Turney CSM, van der Plicht J, Weyhenmeyer CE. 2009. IntCa109 and Marine09 radiocarbon age calibration curves, 0-50,000 years cal BP. Radiocarbon 51(4): 1111-50.

Rieth TM, Hunt TL, Lipo C, Wilshurst JM. 2011. The 13th century Polynesian colonization of Hawai'I Island. Journal of Archaeological Science 38(10):27409.

Sikes EL, Samson CR, Guilderson TP, Howard WR. 2000. Old radiocarbon ages in the southwest Pacific Ocean during the last glacial period and deglaciation. Nature 405(6786):555-9.

Specht J. 2009. The aceramic to ceramic boundary in the Bismarck Archipelago. In: Sheppard PJ, Thomas T, Summerhayes GR, editors. Lapita. Ancestors and Descendants. Auckland: New Zealand Archaeological 
Association Monograph 28. p 11-34.

Specht J, Gosden C. 1997. Dating Lapita Pottery in the Bismarck Archipelago, Papua New Guinea. Asian Perspectives 36(2):175-94.

Specht J, Summerhayes G. 2007. The Boduna Island (FEA) Lapita site. Archaeological studies of the Middle and Late Holocene, Papua New Guinea, Part II. Technical Reports of the Australian Museum 20:51103.

Steinberg CR, Choukroun SM, Slivkoff MM, Mahoney MV, Brinkman RM. 2006. Currents in the Bismarck Sea and Kimbe Bay, Papua New Guinea. Australian Institute of Marine Science and The Nature Conservancy. TNC Pacific Island Countries Report No 6/06.

Stuiver M, Braziunas TF 1993. Modeling atmospheric ${ }^{14} \mathrm{C}$ influences and ${ }^{14} \mathrm{C}$ ages of marine samples to 10,000 BC. Radiocarbon 35(1):137-89.

Stuiver M, Pearson GW, Braziunas T. 1986. Radiocarbon age calibration of marine samples back to $9000 \mathrm{cal} \mathrm{yr}$ BP. Radiocarbon 28(2B):980-1021.

Stuiver M, Reimer PJ, Braziunas TF. 1998. High-precision radiocarbon age calibration for terrestrial and marine samples. Radiocarbon 40(3):1127-51.

Summerhayes GR. 2007. The rise and transformation of Lapita in the Bismarck Archipelago. In: Chui S, Sand C, editors. From Southeast Asia to the Pacific. Archaeological Perspectives on the Austronesian Expansion and the Lapita Cultural Complex. Taipei: Academic Sinica. p 129-72.

Summerhayes G. 2010. Lapita interaction: an update. In: Gadu M, Hsiuman L, editors. 2009 International Sym- posium on Austronesian Studies. Taitong: National Museum of Prehistory. p 11-40.

Swift MJ, Heal OW, Anderson JM. 1979. Decomposition in Terrestrial Ecosystems. Melbourne: Blackwell Scientific Publications.

Tanaka N, Monaghan MC, Rye DM. 1986. Contribution of metabolic carbon to mollusc and barnacle shell carbonate. Nature 320(6062):520-3.

Ulm S. 2002. Marine and estuarine reservoir effects in central Queensland, Australia: determination of $\Delta \mathrm{R}$ values. Geoarchaeology: An International Journal 17(4):3119-48.

Ulm S, Petchey F, Ross A. 2009. Marine reservoir corrections for Moreton Bay, Australia. Archaeology in Oceania 43(2):160-8.

White JP. 2007. Ceramic sites on the Duke of York Islands. In: Specht J, Attenbrow V, editors. Archaeological Studies of the Middle and Late Holocene, Papua New Guinea. Technical Reports of the Australian Museum 20:3-50.

Wilmshurst JM, Hunt TL, Lipo CP, Anderson AJ. 2010. High-precision radio-carbon dating shows recent and rapid colonization of East Polynesia. Proceedings of the National Academy of Sciences of the USA 108: 1815-20.

Yu K, Hua Q, Zhao J-X, Hodge E, Fink D, Barbetti M. 2010. Holocene marine ${ }^{14} \mathrm{C}$ reservoir age variability: evidence from ${ }^{230} \mathrm{Th}$-dated corals in the South China Sea. Paleoceanography 25: PA3205, doi:10.1029/ 2009PA001831. 